\title{
Potrait of Poverty and Related Categories Human Development Index (HDI) District/City In East Java (2005-2014)
}

\author{
Dr. Hadi Sumarsono ${ }^{1}$, Lysia Novarinda ${ }^{2}$ \\ ${ }^{1}$ (Department of Economics, Faculty of Economics, Universitas Negeri Malang, Indonesia) \\ ${ }^{2}$ (Department of Economics, Faculty of Economics, Universitas Negeri Malang, Indonesia)
}

\begin{abstract}
Development is a tool used to archieve the goals of the nation and the economic growth is one indicator to assess the success of the development of a country. Economic growth has been and will remain to cornerstone of poverty reduction. This study analysis the poverty and Human Develpment Index (HDI) of East Java Province by using cointegration test. The time frame of this study began in 2005-2014. The scope of this study conducted in 38 districts/municipalities in East Java Province. In general HDI variable inrease, while the variable of poverty has decreased in East Java Province during the period 2005-2014. Result of data if there are 15 districts/cities that fall into Quandrant 1 which has a high HDI value and the percentage of low poverty. Quadrant 2 there are four district that have a lower HDI values and the percentage of high poverty. Quadrant 3 that have eight district that have a lower value and the percentages of low poverty. Quadrant 4 there are 11 districts that have a lower HDI value and the percentage of high poverty. Based on the result if the data that urban areas occupy the first quadrant. As a for areas that are in quadrant 4 is the district.
\end{abstract}

Keywords: Poverty, Human Development Index, Cointegration Test

\section{Introduction}

Development is a tool used to achieve the goals of the nation and the economic growth is one indicator to assess the success of the development of a country. Objective Development is a development paradigm that is emerging today is economic growth measured by human development are viewed with the level of quality of life in each country. One of the benchmarks used in looking at the quality of human life is the Human Development Index (HDI) which is measured by the quality level of education, health and economic (purchasing power). Through increased three indicators is expected to be an increase in the quality of human life.

Economic growth has been and will remain the cornerstone of poverty reduction. Poverty can make the effects serious enough for human development because of the problem of poverty is a complex problem actually stems from the purchasing power of people who are not able to meet the basic needs so that the other needs such as education and health was neglected. Poverty has long been a problem of Indonesia, and until now they have not shown signs of disappearing. The statistics continued to provide information is the large number of poor people, based on data from the Central Bureau of Statistic (BPS) number of poor Indonesia people in 2010 was 31.02 million (13.33\%), while in the province of East Java 14.87\%.

Tabel 1.1 Human Development Index (HDI) and Poverty in East Java Province 2005-1014

\begin{tabular}{|c|c|c|}
\hline YEAR & HDI & POVERTY (\%) \\
\hline 2005 & 68,42 & 19,95 \\
\hline 2006 & 69,18 & 21,09 \\
\hline 2007 & 69,78 & 19,98 \\
\hline 2008 & 70,38 & 18,19 \\
\hline 2009 & 71,06 & 16,22 \\
\hline 2010 & 71,62 & 14,87 \\
\hline 2011 & 72,18 & 13,85 \\
\hline 2012 & 72,83 & 13,08 \\
\hline 2013 & 73,54 & 12,73 \\
\hline 2014 & 68,37 & 12,28 \\
\hline
\end{tabular}

Source: Central Bureau of Statistics/BPS (Data Processed)

According to BPS data that the HDI data in East Java is increasing or better, but only in 2014 has decreased. While data Province percentage of poor population in East Java tends to decrease. However, the need for in-depth analyzed existing data on the relationship of human development and economic growth (poverty). This makes the human development gap between them becomes large and eventually HDI achievement targets set by the government be realized well. New growth theory emphasizes the importance of the role of government, especially in promoting development of human capital improving the quality of human resources can be demonstrated by the increased knowledge and skills of a person. Improved knowledge and expertise will 
be able to encourage increased labor productivity so that someone will be able to assist in reducing poverty (Suliswanto, 2010). The relationship between HDI and poverty makes the researchers wanted to know more. Thus the relevance of human development and poverty can be understood both directions, namely the impact of human development on poverty and the effects of poverty on human development.

\section{Economic Growth}

\section{Theoretical Framework}

The theory of macroeconomic growth in the past that saw economic growth limited due to the nature of the scarcity of natural resources and poverty of workers according Kuncoro (2010). Furthermore, according to Boediono (1988) economic growth is the increase in output per capita in the long run. Economic growth is a process, not an economic picture at a time. So an economy can be said to grow if in the long term more than five years and experienced an increase in output per capita.

According to Boediono (1988) The theory of economic growth can we define as an explanation of what factors are menentykan increase in output per capita in the long run, and an explanation of how these factors interact with each other, resulting in the growth process.

\section{Human Development Index (HDI)}

According to the Central Bureau of Statistics (BPS) Humans are the real wealth of nations. Human development puts human beings as the ultimate goal of development and not a tool of development. The main objective of development is to create an environment that allows people to enjoy longevity, healthy, and run a productive life (United Nations Development progamme-UNDP). Human development Index is defined as a process of enlarging people's choices. HDI explain how residents can access development results in obtaining income, health, education, and so forth. HDI was introduced by UNDP in 1990 and published periodically in the annual report of the Human Development Report (HDR). HDI was formed by three (3) basic dimensions: a long and healthy life Age, knowledge and a decent standard of living (decent standard of living). HDI benefits include:

1. The HDI is an important indicator to measure success in the effort to build the quality of human life (community/population).

2. HDI can rank or level of development divulging region/country.

3. For Indonesia, the HDI is strategic because in addition to the data as a measure of the Government's performance, HDI is also used as one allocator determining the General Allocation Fund.

\section{Poverty}

Poverty is defined as a condition when a person or group of people unable to meet their basic rights to maintain and develop a life of dignity (Pudjianto, 2015). According to Nugroho, et al (2012) Poverty is a condition of absolute or relative where a person or group of people in a region for reasons of natural, cultural, or structural, cause he does not have the ability to meet basic needs corresponding values or certain norms that different in society. Poverty basically showed the existence of a gap between the weakness of purchasing power (positive) and the desire to meet the basic needs (normative). Poverty can be divided into two: the relative poverty and absolute poverty. According to Todaro (2000) of absolute poverty is the number of people living below the "international poverty line" or less than a certain minimum income level

\section{The Scope of Research}

\section{Research Methods}

In this study analyzes poverty and the Human Development Index (HDI) of East Java Province using the method of cointegration. The timeframe of this study began in 2005-2014. The scope of this study conducted in 38 districts/municipalities in East Java province.

\section{Types and Sources of Data}

According to Firdaus (2012) Data panel is a combination of time series data and slice latitude; the results of observation of a set of objects on a long period of time. There are two advantages compared to the use of panel data model time series data or cross section alone (Verbeek, 2004 in Paradise, 2013). First by combining data time series and cross section in the data panel to make the number of observations to be larger. By using a panel data model marginal effect of the explanatory variables viewed in two dimensions (people and time) so that the parameters that were estimated to be more accurate than other models. Technically according to Hsiao, 2004 in Paradise (2013) panel data can provide informative data, reduce collinearity between variables, as well as increasing the degree of validity, which means increased efficiency. Second, the advantages are more important than the use of panel data is to reduce identification. 
This research uses panel data that is a combination of time series data of 9 years and cross section data for 38 districts/municipalities in East Java province, thus forming the amount of data that must be observed as many as 360 of data (38 District/City during the period of 9 years). Sources of data obtained through secondary data documentation. The data used in this study, namely HDI and Poverty District/City of East Java Province. Data were obtained from published reports the Central Bureau of Statistics. All data taken in the period 20052014.

\section{Analysis method}

According to Creswell (2014) is a quantitative research methods to test certain theories by examining the relationship between variables. These variables are usually measured with instruments so that data yanng study consisted of figures can be analyzed by statistical procedures. This research analysis method using quantitative analysis with panel data. Model analysis used to see the pattern of poverty relationship with the Human Development Index (HDI) in the District/City of East Java Province.

\section{Unit Root Test}

According to Firdaus (2013) Unit Root Test is a test of all the variables if it is stationary. Test stationary or unit root test used to view a stationary time series data.The use of stationary data will produce a regression false or spurious regression. Data panel is a combination of time series and cross section, then the stationary test phase will also be necessary. There is a difference in a stationary test panel data with a stationary test on time series data, this is due to the influence of individual and time.

\section{Co integration test}

Cointegration is a long-term relationship between the variables individually although not stationary, but a linear combination of these variables become stationary. According to Firdaus (2013) The two variables are not stationary before dideferensi but stationary in the firt defference are likely to occur kointegraasi, meaning that there is a long-term relationship between the two. There are three ways to test cointegration, namely: 1) Test Cointegration Elgle -Granger, 2. Cointegrating Regression Test Durbin Watson (CRDW), and 3, Johannsen Cointegrating test. If the data is analyzed is not stationary but mutually cointegrated, there is a long-term relationship or balance between these two variables. In the short term, there may be an imbalance (disequilibrium).

\section{Result and Discussion}

The development of the Human Development Index (HDI) of 2013 issued by the Human Development Report shows that Indonesia's HDI is ranked 108 of 150 countries listed. Overall Human Development Index in Indonesia increased. In 2010 at 66.53, 67.09 2011sebesar year, the year 2012 amounted to 67.70, in 2013 and 2014 amounted to 68.31 at 68.90. If seen in the province of East Java in general HDI experience from year to year. In 2010 at 65.36, at 66.06 2011 year, in 2012 amounted to 66.74, in 2013 amounted to 67.55 and in 2014 amounted to 68.14 .

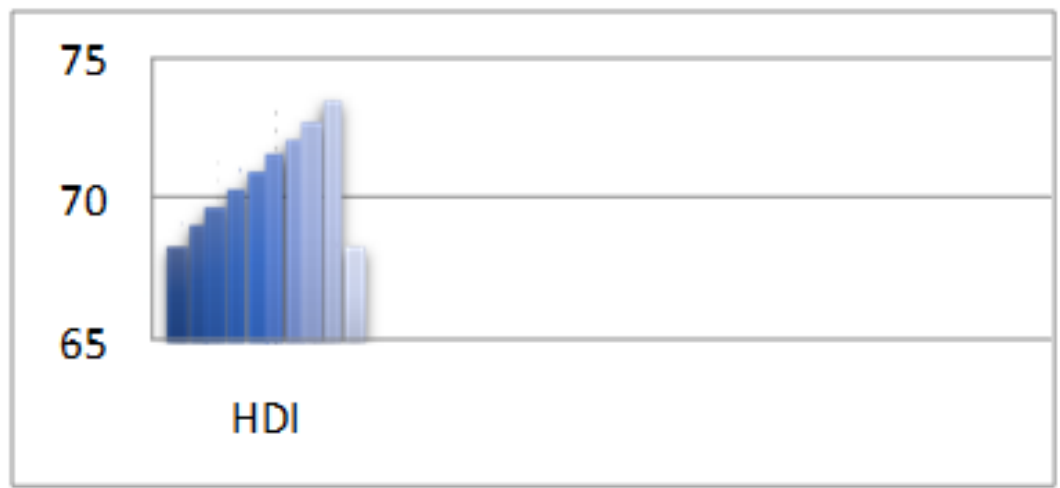

Figure 1.1 Graph Human Development Index (HDI) in the province of East Java in 2005-201

In the graph shown there has been increased HDI in the District/City in the province of East Java in 2005-2014. The development of HDI, HDI show that increase line with the improving economy of the country. 


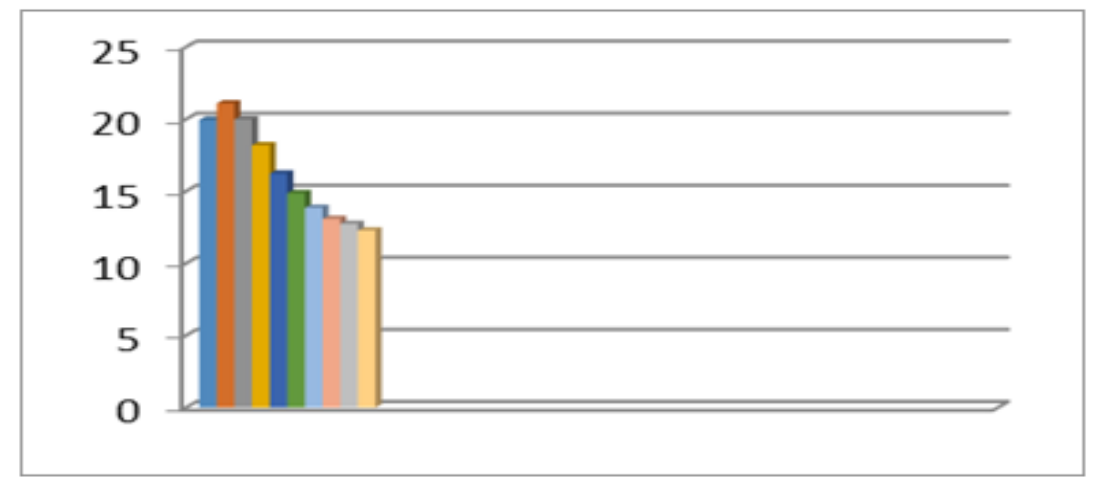

Figure 1.2 Graph Poverty in the District/City of East Java Province 2005-2014

In the graph shown there has been a decline in poverty in the District / City in the province of East Java in 2005-2014. In this analysis of the theories of Typology Klassen, Typology Klassen grouping regions based upon two characteristics that have the area that is the Human Development Index and the rate of economic growth. In this study, the rate of economic growth replaces it with the poverty. Because of the economic growth has been and will remain the cornerstone of poverty reduction.

Table 1.1 Results Classify Districts / City in East Java province into four quadrants

\begin{tabular}{|l|l|l|}
\hline \multicolumn{1}{|l|}{ HDI } & Low Poverty & High poverty \\
\cline { 1 - 3 } High HDI & Tulungangung District, Blitar District, & Pacitan District, Trenggalek District, Gresik \\
& Kediri District, Sidoarjo District, & District dan Probolinggo District. \\
& Jombang District, Magetan District, & \\
\hline Kediri, Blitar, Malang, Pasuruan, & \\
\hline Low HDI & Mojokerto, Madiun, Surabaya, Batu. & Madiun District, Ngawi District, Bojonegoro \\
& Lonorogo District, Malang District, & District, Tuban District, Lamongan District, \\
& Banyang District, Jember District, & Bangkalan District, Sampang District, \\
& Pasuruan District and Nganjuk District. & Pamekasan District, Sumenep District, \\
& & Probolinggo District, Bondowoso District. \\
\hline
\end{tabular}

Analysis of data used to classify the Districts/City in East Java province into four quadrants. Quadrant 1 Districts/City that have high HDI values and the percentage of low poverty. There are 15 districts/municipalities comprising the Tulungangung District, Blitar District, Kediri District, Sidoarjo District, Jombang District, Magetan District, Kediri, Blitar, Malang, Pasuruan, Mojokerto, Madiun, Surabaya, Batu. Quadrant 2 Districts/City that have high HDI values and the percentage of high poverty. There are four district consisting of Pacitan, Trenggalek, Gresik and Probolinggo District. Quadrant 3 District/City which has a low HDI value and the percentage of low poverty. There are 8 district that consists of Ponorogo, Malang, Lumajang, Jember, Banyuwangi, Situbondo, Pasuruan and Nganjuk District. Quadrant 4 District/City thinking about the low HDI value and the percentage of high poverty. There are 11 districts, Madiun, Ngawi, Bojonegoro, Tuban, Lamongan district, Bangkalan, Sampang, Pamekasan, Sumenep, Probolinggo, and Bondowoso District. Based on the results if the data that urban areas occupy the first quadrant. As for areas that are in quadrant 4 is the district.

\section{Unit Root Test Results}

Tabel 1.2 Variable Unit Root Test Results Human Development Index

Panel unit root test: Summary

Series: HDI

Date: 05/04/16 Time: 08:32

Sample: 20052014

Exogenous variables: Individual effects

User-specified lags: 1

Newey-West automatic bandwidth selection and Bartlett kernel

Balanced observations for each test 


\begin{tabular}{|c|c|c|c|c|}
\hline Method & Statistic & Prob.** & $\begin{array}{c}\text { Cross- } \\
\text { sections }\end{array}$ & Obs \\
\hline \multicolumn{5}{|c|}{ Null: Unit root (assumes common unit root process) } \\
\hline Levin, Lin \& Chu t* & -3.61036 & 0.0002 & 38 & 304 \\
\hline \multicolumn{5}{|c|}{ Null: Unit root (assumes individual unit root process) } \\
\hline Im, Pesaran and Shin W-stat & -1.12593 & 0.1301 & 38 & 304 \\
\hline $\mathrm{ADF}$ - Fisher Chi-square & 83.2132 & 0.2672 & 38 & 304 \\
\hline PP - Fisher Chi-square & 81.0325 & 0.3252 & 38 & 342 \\
\hline
\end{tabular}

** Probabilities for Fisher tests are computed using an asymptotic Chi-square distribution. All other tests assume asymptotic normality.

Table 1.3 Variable Unit Root Test Results Poverty

Panel unit root test: Summary

Series: Poverty

Date: 05/04/16 Time: 08:33

Sample: 20052014

Exogenous variables: Individual effects

User-specified lags: 1

Newey-West automatic bandwidth selection and Bartlett kernel

Balanced observations for each test

\begin{tabular}{lcccc}
\hline \hline & \multicolumn{3}{c}{ Cross- } \\
Method & Statistic & Prob.** & sections & Obs \\
\hline Null: Unit root (assumes common unit root process) & & \\
\hline \multicolumn{7}{l}{ Levin, Lin \& Chu t* } & -30.5376 & $\mathbf{0 . 0 0 0 0}$ & 38 & 304 \\
& & & \\
Null: Unit root (assumes individual unit root process) & & 304 \\
\hline Im, Pesaran and Shin W-stat & -8.72132 & 0.0000 & 38 & 304 \\
ADF - Fisher Chi-square & 234.975 & 0.0000 & 38 & 342 \\
PP - Fisher Chi-square & 34.0443 & 1.0000 & 38 & \\
\hline \hline
\end{tabular}

** Probabilities for Fisher tests are computed using an asymptotic Chi-square distribution. All other tests assume asymptotic normality.

\section{Co integration Test Results}

Table 1.4 Co integration Test Results between Poverty by HDI

Pedroni Residual Cointegration Test

Series: HDI Poverty

Date: 05/04/16 Time: 08:35

Sample: 20052014

Included observations: 380

Cross-sections included: 38

Null Hypothesis: No cointegration

Trend assumption: No deterministic trend

User-specified lag length: 1

Newey-West automatic bandwidth selection and Bartlett kernel

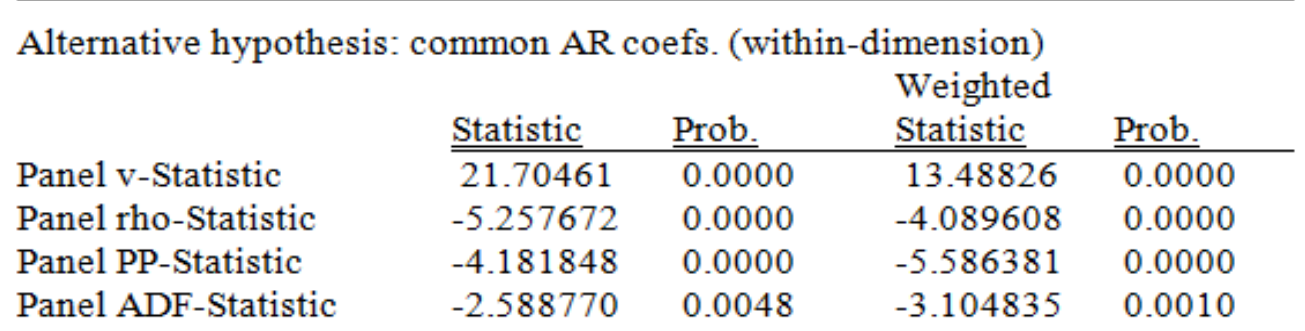


Potrait of Poverty and Related Categories Human Development Index (HDI) District/City in East....

Alternative hypothesis: individual AR coefs. (Between-dimension)

Statistic Prob.

$\begin{array}{lll}\text { Group rho-Statistic } & -1.962975 & 0.0248 \\ \text { Group PP-Statistic } & -5.553771 & 0.0000 \\ \text { Group ADF-Statistic } & -3.046516 & 0.0012\end{array}$

Cross section specific results

Phillips-Peron results (non-parametric)

\begin{tabular}{|c|c|c|c|c|c|}
\hline Cross ID & $\overline{\mathrm{AR}(1)}$ & Variance & $\mathrm{HAC}$ & Bandwidth & Orbs \\
\hline 1 & -0.199 & 7.386471 & 7.178334 & 1.00 & 9 \\
\hline 2 & -0.327 & 2.073858 & 1.650327 & 2.00 & 9 \\
\hline 3 & -0.247 & 5.495683 & 5.343542 & 1.00 & 9 \\
\hline 4 & -0.280 & 2.063725 & 1.680121 & 2.00 & 9 \\
\hline 5 & -0.285 & 5.016224 & 5.016224 & 0.00 & 9 \\
\hline 6 & 0.033 & 2.004216 & 1.875821 & 1.00 & 9 \\
\hline 7 & -0.432 & 3.336646 & 3.168937 & 1.00 & 9 \\
\hline 8 & -0.303 & 3.919229 & 3.763848 & 1.00 & 9 \\
\hline 9 & -0.394 & 1.110484 & 1.028727 & 1.00 & 9 \\
\hline 10 & -0.435 & 0.962002 & 0.547653 & 4.00 & 9 \\
\hline 11 & -0.222 & 0.391580 & 0.114878 & 6.00 & 9 \\
\hline 12 & 0.179 & 0.782006 & 0.702712 & 1.00 & 9 \\
\hline 13 & 0.254 & 0.662062 & 0.662062 & 0.00 & 9 \\
\hline 14 & -0.537 & 1.943185 & 1.633684 & 2.00 & 9 \\
\hline 15 & 0.263 & 0.384467 & 0.404922 & 1.00 & 9 \\
\hline 16 & -0.602 & 1.665905 & 1.665905 & 0.00 & 9 \\
\hline 17 & -0.515 & 2.041698 & 1.707275 & 2.00 & 9 \\
\hline 18 & -0.373 & 0.576069 & 0.348752 & 3.00 & 9 \\
\hline 19 & -0.285 & 0.676857 & 0.655783 & 1.00 & 9 \\
\hline 20 & -0.672 & 0.966170 & 0.880204 & 1.00 & 9 \\
\hline 21 & -0.204 & 0.819118 & 0.667365 & 2.00 & 9 \\
\hline 22 & -0.374 & 0.671636 & 0.617783 & 1.00 & 9 \\
\hline 23 & -0.410 & 2.053935 & 2.053935 & 0.00 & 9 \\
\hline 24 & -0.239 & 0.452498 & 0.278196 & 3.00 & 9 \\
\hline 25 & -0.321 & 0.915819 & 0.618511 & 3.00 & 9 \\
\hline 26 & 0.061 & 2.769455 & 2.769455 & 0.00 & 9 \\
\hline 27 & -0.206 & 2.629116 & 2.556782 & 1.00 & 9 \\
\hline 28 & -0.347 & 1.512637 & 0.951020 & 3.00 & 9 \\
\hline 29 & -0.183 & 2.484001 & 2.484001 & 0.00 & 9 \\
\hline 30 & -0.587 & 0.628791 & 0.571143 & 1.00 & 9 \\
\hline 31 & -0.597 & 0.725609 & 0.590586 & 2.00 & 9 \\
\hline 32 & 0.047 & 0.293145 & 0.233136 & 3.00 & 9 \\
\hline 33 & 0.339 & 2.657851 & 2.546210 & 1.00 & 9 \\
\hline 34 & 0.287 & 0.511991 & 0.511991 & 0.00 & 9 \\
\hline 35 & -0.557 & 0.817960 & 0.665191 & 2.00 & 9 \\
\hline 36 & 0.273 & 0.134244 & 0.166548 & 1.00 & 9 \\
\hline 37 & 0.042 & 0.259799 & 0.209405 & 1.00 & 9 \\
\hline 38 & -0.403 & 1.189861 & 0.751078 & 3.00 & 9 \\
\hline
\end{tabular}


Augmented Dickey-Fuller results (parametric)

\begin{tabular}{|c|c|c|c|c|c|}
\hline Cross ID & AR(1) & Variance & Lag & Max lag & Orbs \\
\hline 1 & -0.368 & 8.138667 & 1 & - & 8 \\
\hline 2 & -0.717 & 2.112480 & 1 & - & 8 \\
\hline 3 & -0.512 & 5.919094 & 1 & - & 8 \\
\hline 4 & -0.856 & 1.804229 & 1 & - & 8 \\
\hline 5 & -0.408 & 5.591222 & 1 & $\ldots$ & 8 \\
\hline 6 & -0.177 & 2.159666 & 1 & - & 8 \\
\hline 7 & -0.647 & 3.669043 & 1 & - & 8 \\
\hline 8 & -0.506 & 4.301415 & 1 & - & 8 \\
\hline 9 & -0.612 & 1.212477 & 1 & - & 8 \\
\hline 10 & -1.018 & 0.859236 & 1 & - & 8 \\
\hline 11 & -0.749 & 0.254135 & 1 & $\ldots$ & 8 \\
\hline 12 & 0.288 & 0.783578 & 1 & - & 8 \\
\hline 13 & 0.249 & 0.734151 & 1 & - & 8 \\
\hline 14 & -0.962 & 2.002769 & 1 & $\ldots$ & 8 \\
\hline 15 & -0.016 & 0.396838 & 1 & -. & 8 \\
\hline 16 & -0.443 & 1.693973 & 1 & - & 8 \\
\hline 17 & -1.080 & 2.012379 & 1 & $\ldots$ & 8 \\
\hline 18 & -0.822 & 0.551792 & 1 & - & 8 \\
\hline 19 & -0.473 & 0.732468 & 1 & - & 8 \\
\hline 20 & -0.979 & 1.041556 & 1 & - & 8 \\
\hline 21 & -0.574 & 0.820954 & 1 & - & 8 \\
\hline 22 & -0.646 & 0.726662 & 1 & - & 8 \\
\hline 23 & -0.563 & 2.287156 & 1 & - & 8 \\
\hline 24 & -0.670 & 0.421053 & 1 & $\ldots$ & 8 \\
\hline 25 & -0.740 & 0.889020 & 1 & - & 8 \\
\hline 26 & 0.129 & 3.079688 & 1 & -- & 8 \\
\hline 27 & -0.455 & 2.776081 & 1 & - & 8 \\
\hline 28 & -1.290 & 1.125430 & 1 & - & 8 \\
\hline 29 & -0.305 & 2.756472 & 1 & - & 8 \\
\hline 30 & -0.857 & 0.677934 & 1 & $\ldots$ & 8 \\
\hline 31 & -1.108 & 0.751230 & 1 & - & 8 \\
\hline 32 & -0.329 & 0.167065 & 1 & - & 8 \\
\hline 33 & 0.121 & 2.667198 & 1 & $\ldots$ & 8 \\
\hline 34 & 0.213 & 0.570449 & 1 & $\ldots$ & 8 \\
\hline 35 & -1.058 & 0.845697 & 1 & - & 8 \\
\hline 36 & 0.681 & 0.104389 & 1 & -. & 8 \\
\hline 37 & -0.248 & 0.265708 & 1 & $\ldots$ & 8 \\
\hline 38 & -0.913 & 1.152331 & 1 & - & 8 \\
\hline
\end{tabular}

\section{Conclusion}

In general, the HDI variables in the province of East Java during the period 2005 to 2014 have increased. While variable general poverty decreased from the year 2005 to 2014. Condition 3 highest HDI in the province of East Java, Kota Blitar, Surabaya and Malang City. While the three lowest poverty conditions in the province of East Java city of Malang, Madiun and Batu.

The results of data analysis HDI and poverty used to classify the Regency/City in East Java province into four quadrants. There are 15 districts/cities that fall into quadrant 1 . There are four districts that fall into quadrant 2. There are 8 districts included in quadrant 3. And there are 11 districts that are in quadrant 4. Based on the results of data processing that urban areas occupy the first quadrant, As for areas that are in quadrant 4 is the district. Based on the results of cointegration test shows that there is a long-term equilibrium relationship between HDI with Poverty in regencies/cities in East Java province.

\section{References}

[1] Badan Pusat Statistik, Bloknote Indeks Pembangunan Manusia, online (www.bps.go.id), accessed on april $20,2016$.

[2] Badan Pusat Statistik, online,(www.bpsjatim.go.id), accessed on april 20, 2016.

[3] Badan Pusat Statistik, Indeks Pembangunan Manusia, online (https://www.bps.go.id/website/pdf_publikasi/Indeks-PembangunanManusia-2014_rev.pdf) diakses accessed on april 20, 2016.

[4] Badan Pusat Statistik, Kemiskinan, online (https://www.bps.go.id/website/pdf_publikasi/Data-dan-Informasi-KemiskinanKabupaten-Kota-2009) accessed on april 2016.

[5] Badan Pusat Statistik, Kemiskinan, online (https://www.bps.go.id/website/pdf_publikasi/Data-dan-Informasi-KemiskinanKabupaten-Kota-2010.pdf) accessed on april 2016. 
[6] Badan Pusat Statistik, Kemiskinan, online https://www.bps.go.id/website/pdf_publikasi/watermark\%20_Data\%20dan\%20Informasi \%20Kemiskinan\%20Kabupaten_Kota\%202011.pdf) accessed on april 2016.

[7] Creswell, J.W, RESEARCH DESIGN Pendekatan Kualitatif, Kuantitatif, dan Mixed, (Pustaka Belajar: Yogyakarta, 2014)

[8] Kuncoro. M, Dasar-Dasar EKONOMIKA PEMBANGUNAN, (UPP STIM YKPN: Yogyakarta, 2010)

[9] Kuncoro. M, Masalah, Kebijakan, dan Politik EKONOMIKA PEMBANGUNAN, (Erlangga: Jakarta, 2010).

[10] Lumbantouruan, Eka Pratiwi et al, Analisis Pertumbuhan Ekonomi dan Indeks Pembangunan Manusia (IPM) Provinsi-Provinsi di Indoesia (Metode Kointegrasi), 2016, Jurnal Ekonomi dan Keuangan, Vol.2 No. 2, hal 14-27, online accessed on april 2016.

[11] Muhammad, F, 2012, Aplikasi Ekonomietrika untuk Data Panel dan Time Series, PT Penerbit IPB Press: Bogor.

[12] Nugroho, I et al, 2012, Pembangunan Wilayah: Persepektif Ekonomi Sosial dan Lingkungan, LP3ES: Jakarta.

[13] Pudjianto, B \& Syawie, 2015, Kemiskinan Dan Pembangunan Manusia Poverty And Human Development Pusat Penelitian dan Pengembangan Kesejahteraan Sosial, Kementerian Sosial RI, Sosio Informa Vol. 1, No. 03, September - Desember, Tahun 2015. Online accessed on april 2016.

[14] Suliswanto. Muhammad Sri Wahyudi, 2010, Pengaruh Produk Domestik Bruto (PDB) Dan Indeks Pembangunan Manusia (IPM) Terhadap Angka Kemiskinan Di Indonesia Jurnal Ekonomi Pembangunan, Vol 8 No. 2 Desember 2010. accessed on april 2016.

[15] Todaro, Michael P, 2000, PEMBANGUNAN EKONOMI di Dunia Ketiga (Edisi Ketuju/Jilid 1), PT. GELORA AKSARA PRATAMA:Jakarta, 